\title{
An Empirical Study on the Effect of Management Service Quality of High-Rise Apartment on Residential Satisfaction: Focused on High- Rise Apartment in China
}

\author{
Feng Jing ${ }^{1}$ and Chae-Kwan Lim $^{2 *}$ \\ ${ }^{1}$ Graduate Student, Doctor's degree, Dept. of Business Administration, Tongmyong \\ University, Sinsun-Ro 428, Nam-gu, Busan, Korea \\ ${ }^{2}$ Professor, Dept. of Distribution Management, Tongmyong University., Sinsun-Ro \\ 428, Nam-gu, Busan, Korea \\ 1jingfengkorea@naver.com, ${ }^{2}$ cklim@tu.ac.kr
}

\begin{abstract}
Recently, high-rise apartments are being built around large cities in China. This study examined the relationship between the evaluation of the management services quality perceived by residents and the satisfaction and recommendation intention of tenants living in high-rise apartments in China. The purpose of this study is to empirically examine the relationship between tenant's management service quality, satisfaction, and recommendation intention in a high-rise apartment' in a large city in China. The results showed that the quality of management services of high-rise apartments had a significant effect on occupancy satisfaction. In addition, among the quality of management service affecting occupancy satisfaction and recommendation intention, the relationship was the highest in the order of process quality, result quality, and environmental quality.
\end{abstract}

Keywords: High-rise apartments, Environmental quality, Process quality, Result quality, Satisfaction, Recommendation

\section{Introduction}

High-rise residential complex apartments that have recently been built in the metropolitan area within China are precious residential spaces for residents, not only offering differentiated and advanced convenience but also maintaining somewhat higher price of properties. Especially, as the entire society is being converted into service-centered economy and its subsequent competition mounts, even in the case of building maintenance, demand for some advanced service has increased. Accordingly, the necessity for policies in the field of building maintenance emerged that improve the quality of property maintenance service and increase customers' satisfaction on all kinds of management services. Despite of such practical necessity, however, the empirical study as to the management service of high-rise residential complex apartment is not very active. Hence, this study has the purpose of making an academic basis of providing more comfortable and convenient residential environment through consumer-centered housing supply in high-rise residential complex apartments by evaluating the quality of management service of residents in high-rise residential complex

Article history:

Received (April 14, 2020), Review Result (May 16, 2020), Accepted (June 19, 2020) 
apartment in China and investigating residents' satisfaction and recommendation intention in the apartment.

This study investigates the characteristics of consumer choice behavior by surveying residents of high-rise residential complex in the Chinese metropolitan area and examines their attitudes, experiences and cognitive behaviors about the management service of high-rise residential complex, with which this study examines residents' satisfaction and recommendation intention on the complex through the aspects of residential use.

\section{Literature review}

\subsection{The status of high-rise buildings in China}

The history of high-rise building beginning from the late 19th century spans around 100 years to the end of the 20th century. On account that the term 'high-rise' implies a little relative concept, it cannot be reduced to a uniform definition. Today, the commonly used standard to indicate whether a building is high-rise or not is based on the definitions of CTBUH-Council on Tal Buildings and Urban Habitat. According to the standard, high-rise building is defined as a building having a height of $20 \mathrm{~m}$ or more or 50 stories or more, or a ratio of the bottom and height of 1:5 or more, and one determined by existence of lateral load resistance system [1].

Table 1. Current status of tall buildings in China (Based on 2018)

\begin{tabular}{|c|c|c|c|c|}
\hline Total No.of high-rise building & Over 100M & Over 150M & Over 200M & Over 300M \\
\hline 3,867 & 2,575 & 1,862 & 678 & 68 \\
\hline
\end{tabular}

As of 2018, China has 3,867 high-rise buildings that meet the definition of Chinese Building Act. There are 2,575 buildings over $100 \mathrm{~m}$ in height, 1,862 buildings over $150 \mathrm{~m}, 678$ buildings over $200 \mathrm{~m}$, and 68 buildings over $300 \mathrm{~m}$. Among these, buildings over $150 \mathrm{~m}$ account for much more than any other country in the world. In 2018, China built 88 high-rise buildings with more than 200 meters high, making itself become the first in the world, followed by the United States which built 13 buildings. However, the number of high-rise buildings over $100 \mathrm{~m}$ built by China in 2018 is overwhelmingly over six times more than the US. That accounts for $61.5 \%$ of the world's high-rise buildings built in 2018. In addition, China has renewed the record of building tall buildings annually. 88 constructions were made in 2018, surpassing 86 constructions in 2016, and in 2017, 80 high-rise buildings over $200 \mathrm{~m}$ were built.

\subsection{Management service quality}

The quality of service is generally defined not as a concept of objective quality but that of subjective quality, and can be defined by the meaning of 'perceived service quality' by consumers. This means that the quality of service offered should be consistent with customer's expectation while service quality is defined as a measure of how well the service level provided matches the customer's expectation [2]. Many scholars support the conceptual definition of Parasuraman et al. which read 'the quality of service is the overall judgment or attitude of an individual in relation to the excellence of a specific service' [3]. It is also shown in Bitner and Hubert's study, which defines service quality as "the overall impression consumers have in relation to the excellence or inferiority of service." Such service quality varies in its diverse theoretical views of the range of services subject to quality assessment. In 
this study, the quality of management service is a customer-oriented concept that measures customer perception which is defined as the attribute of management service and the satisfaction level of customers who encountered a series of service processes. On the basis of such definition, the study composes the sub-factors of management service quality with environmental quality, process quality, and result quality and analyzes their influence relationship with resident satisfaction.

\subsection{Resident satisfaction}

The concept of customer satisfaction is a key element of marketing concept, and many studies have been conducted to present remarkable research results, but there are some differences depending on the approach and perspective of scholars. Oliver also described customer satisfaction as the comprehensive psychological state created by customer's mismatched expectation combined with the emotion that consumer had by consumer's earlier experience of purchase [4]. Engel et al., identified the customer satisfaction as an evaluation [5] of whether the selected product or service matched the beliefs held in advance by customers, and Anderson and Weitz defined it as the process of matching or discrepancy between expectation and perceived product performance [6].

\subsection{The intention of recommendation}

Recommendation, when viewed from the perspective of consumer response, is closely related to the behavior after purchase as well as to the customer's information acquisition and his or her purchase. Because word of mouth can affect the purchase and use experience by delivering customer satisfaction or dissatisfaction to others after purchase, the message from customers has a considerable influence [7]. The intention of recommendation has been studied as a 'verbal phenomenon,' and unlike the entire evaluation of experience called 'satisfaction,' word of mouth is defined as communicative behavioral process of informally exchanging positive or negative information between consumers through direct and indirect experiences of individuals [8].

\section{Empirical study}

\subsection{Research design}

This study sets up the following hypotheses based on a precedent that the management service quality of high-rise apartments has an effect on residents' satisfaction and intention of recommendation.

Hypothesis 1: The quality of management service will have a positive effect on the satisfaction of residents.

1-1 Environmental quality will have a positive effect on residents' satisfaction.

1-2 Process quality will have a positive effect on residents' satisfaction.

1-3 Result quality will have a positive effect on residents' satisfaction.

Hypothesis 2: Satisfaction on the part of residents living in high-rise apartment will have a positive effect on the intention of recommendation.

\subsection{Research method}

The survey for the empirical analysis of this study was conducted for about three months from December 2019 to February 2020 for those who have lived in high-rise apartments in 
China. 265 copies of questionnaire were collected through the online questionnaire method, and 240 copies were finally used for analysis, excluding 25 copies that were insincere. The measurement of variables was made by a five-point scale on environmental quality, process quality, result quality, resident satisfaction, and recommendation intention based on the existing precedent studies related to the management service quality of high-rise apartments.

And SPSS 25.0 was used for statistical process for the analysis on data surveyed. Frequency analysis was conducted to identify the general characteristics of the subjects, and reliability analysis and factor analysis were conducted to verify the reliability and validity of the measurement tools used in the empirical study. Multiple regression analysis was also utilized to examine the research hypotheses.

\section{Result of research}

\subsection{General status of data}

When result characteristics are viewed after analyzing the general status of the data, $48.3 \%$ of the male and $51.7 \%$ of the female were shown in the data. The age of '40s' was the most with 59.6\%, 'Shandung/Shanxi province' with $48.0 \%$, '4-year college graduation' with $30.4 \%$, and 'office worker/public servant' with $28.8 \%$. Besides, residents of 1 year to less than 3 years were the most with $30.4 \%$ and the average monthly household income with less than 2 million won was shown the most with $71.3 \%$.

\subsection{Analysis on the reliability and validity of measurement variables}

This study used Cronbach's $\alpha$ coefficient showing the internal consistency of the data in order to analyze the reliability of the measurement tool.

Table 2. Result of reliability and validity analysis

\begin{tabular}{|c|c|c|c|c|c|}
\hline Factors & Items & factor loading & Cronbach' $\alpha$ & eigen value & Cumulative variance (\%) \\
\hline \multirow{5}{*}{ Environment quality } & EQ1. & .884 & & & \\
& EQ2. & .855 & & & \\
& EQ3. & .827 & .950 & 3.032 & 10.828 \\
& EQ4. & .811 & & & \\
& EQ5. & .787 & & & \\
& EQ6. & .710 & & & \\
& PQ1. & .760 & & & \\
& PQ2. & .755 & & & \\
Process quality & PQ3. & .748 & .954 & 1.387 & \\
& PQ4. & .738 & & & \\
& PQ5. & .720 & & & \\
& PQ6. & .713 & & & \\
\hline \multirow{5}{*}{ Result quality } & RQ1. & .875 & & & \\
& RQ1. & .856 & & & \\
& RQ1. & .855 & .967 & 2.077 & \\
& RQ1. & .834 & & & \\
& RQ1. & .823 & & & \\
\hline \multirow{5}{*}{ Residential } & CS1. & .791 & & & \\
satisfaction & CS2. & .767 & & & \\
& CS3. & .762 & & & \\
& CS4. & .744 & .957 & 15.731 & \\
& CS5. & .732 & & & \\
& CS6. & .731 & & & \\
& CS7. & .686 & & & \\
\hline
\end{tabular}




\begin{tabular}{|c|c|c|c|c|c|}
\hline $\begin{array}{l}\text { Intention of } \\
\text { recommendation }\end{array}$ & $\begin{array}{l}\text { IR1. } \\
\text { IR2. } \\
\text { IR3. } \\
\text { IR4. }\end{array}$ & $\begin{array}{l}.860 \\
.856 \\
.824 \\
.791\end{array}$ & .962 & 1.210 & 4.322 \\
\hline
\end{tabular}

Sample adequacy: Kaiser-Meyer-Olkin, Statistical measure $=.911$, Bartlett spherical test approximation $x 2=8,872.447$ (degree of freedom $=378, p=.000$ )

In addition, factor analysis was conducted to verify the validity of the measurement items. The factor analysis was performed by using the Varimax rotation method by the principal component analysis, and only the factors with the eigen value of 1.0 or more were analyzed. As shown in Table 4, Cronbach' $\alpha$ value is shown to be more than 0.9 for each factor, so it is analyzed to be reliable. In addition, the factor analysis results showed that five factors were derived, and the explanation power of the whole factor was $83.704 \%$.

\subsection{Hypothesis test}

In this study, regression analysis is made to identify the relationship between management service quality, satisfaction and recommendation intention of high-rise residential complex apartments in China. The results are as follows.

First, the verification result of Hypothesis 1 that the quality of management of high-rise apartments will have a positive (+) effect on the satisfaction of residents. As a result of multiple regression analysis, the result of variance analysis for statistical significance verification of the regression coefficient shows that the significance probability value is .000 , which is meaningful with the value of the significance level .01. The result of multiple regression analysis shows that environmental quality, process quality and result quality under the management service quality of high-rise apartments have a statistically significant positive effect on residents' satisfaction, so all hypotheses 1-1, 1-2, and 1-3 are adopted.

Table 3. Result of Hypothesis Test 1

\begin{tabular}{|c|c|c|c|c|c|c|c|}
\hline Distinction & Square sum & d.f & Mean square & $\mathrm{F}$ & $\mathrm{P}$-value & $\mathrm{R}$ & $\mathrm{R}^{2}$ \\
\hline Regression & 85.533 & 3 & 28.511 & 98.019 & $.000 * * *$ & \multirow{3}{*}{.745} & .555 \\
\hline Residual & 68.646 & 236 & 0.291 & & & & Adj.- $R^{2}$ \\
\hline Total & 154.180 & 239 & & & & & .549 \\
\hline \multirow{2}{*}{ Model } & \multicolumn{2}{|c|}{$\begin{array}{l}\text { Non standardization } \\
\text { coefficient }\end{array}$} & \multirow{2}{*}{$\begin{array}{c}\text { Standardization } \\
\text { coefficient(Beta) }\end{array}$} & \multirow{2}{*}{$\mathrm{t}$} & \multirow{2}{*}{ P-value } & \multicolumn{2}{|c|}{$\begin{array}{c}\text { collinear } \\
\text { statistic }\end{array}$} \\
\hline & B & S. E. & & & & Tolerance & VIF \\
\hline (Constant) & .755 & .177 & & 4.266 & .000 & & \\
\hline $\begin{array}{c}\text { Environment } \\
\text { quality }\end{array}$ & .168 & .050 & .200 & 3.319 & $.001 * * *$ & .518 & 1.930 \\
\hline $\begin{array}{l}\text { Process } \\
\text { quality }\end{array}$ & .342 & .064 & .363 & 5.362 & $.000 * * *$ & .411 & 2.431 \\
\hline $\begin{array}{l}\text { Result } \\
\text { quality }\end{array}$ & .269 & .048 & .306 & 5.610 & $.000 * * *$ & .635 & 1.575 \\
\hline
\end{tabular}

Second, the result of verifying Hypothesis 2 that the residents' satisfaction in the research model will have a positive (+) effect on the recommendation intention. As a result of analysis, the analysis of variance shows that the significance probability value is .000 , which is relevant at the significance level .01. As a result of simple regression analysis, the residential 
satisfaction with high-rise apartments had a statistically significant positive effect on the intention of recommendation, and the hypothesis 2 is supported.

Table 4. Result of Hypothesis 2

\begin{tabular}{|c|c|c|c|c|c|c|c|}
\hline Distinction & Square sum & d.f & Mean square & $\mathrm{F}$ & P-value & $\mathrm{R}$ & $\mathrm{R}^{2}$ \\
\hline Regression & 91.958 & 1 & 91.958 & 212.505 & $.000 * * *$ & \multirow{3}{*}{.687} & .472 \\
\hline Residual & 102.991 & 238 & 0.433 & - & - & & Adj. $-R^{2}$ \\
\hline Total & 194.949 & 239 & - & - & - & & .469 \\
\hline \multirow{2}{*}{ Model } & \multicolumn{2}{|c|}{$\begin{array}{c}\text { Non standardization } \\
\text { coefficient }\end{array}$} & \multirow{2}{*}{\multicolumn{2}{|c|}{$\begin{array}{c}\text { Standardization } \\
\text { Coefficient (Beta) }\end{array}$}} & \multirow{2}{*}{$\mathrm{t}$} & \multirow{2}{*}{\multicolumn{2}{|c|}{ P-value }} \\
\hline & B & S. E. & & & & & \\
\hline (Constant) & 1.023 & .202 & \multicolumn{2}{|l|}{ - } & 5.064 & \multicolumn{2}{|c|}{.000} \\
\hline $\begin{array}{l}\text { Customer } \\
\text { satisfaction }\end{array}$ & .772 & .053 & \multicolumn{2}{|c|}{.687} & 14.578 & \multicolumn{2}{|c|}{$.000 * * *$} \\
\hline
\end{tabular}

Dependent variable: the intention of recommendation

$* p<.1, * * p<.05, * * * p<.01$

\section{Conclusion}

This study is to empirically examine how the quality of management service environmental quality, process quality and result quality - perceived by the residents of highrise residential complex of China affects the satisfaction of the residents and how the satisfaction of the residents affects the recommendation intention. The results and implications are as follows. As a result of the empirical analysis, environmental quality, process quality and result quality as sub-factors of management service quality of high-rise apartments in China have a significant effect on the satisfaction of occupancy.

Furthermore, it is thought that the occupancy satisfaction has a significant effect on the recommendation intention. Also, it is shown that the process quality, result quality, and environmental quality among the sub-service quality factors had a great influence in their order. Such results of analysis is similar to those in the existing research on service quality, and it is the result showing that the process of offering service has a great impact on residential satisfaction.

Therefore, in order to improve the satisfaction of the residents of high-rise apartments and to derive positive attitudes and follow-up behaviors, it can be said that it is important to give priority to paying attention to residents' requirements and taking a quick and friendly treatment of them rather than focusing on making efforts to improve the physical environment quality and its resulting increase of quality.

However, this study has limitations of its scope and samples because it confined its survey into limited period and some specific areas in China. Therefore, it seems to be necessary to expand the scope of the survey in order to overcome these limitations and to continue to study the various conditions of the residence, such as the development of measurement items proactively reflecting the characteristics of the residence in high-rise apartments.

\section{References}

[1] CTBUH, “The status of newly built tall buildings in 2018," CTBUH, (2018) 
[2] Parasuraman A., Valarie A. Zeithaml, and Leonard L. Bery, "A conceptual model of service quality and its implications for future research," Journal of Marketing, vol.49, no.4, pp.41-50, (1985) DOI: $10.1177 / 002224298504900403$

[3] Rust R. T. and R. L. Oliver, "Service quality: insights and managerial implications from the frontier, in service quality: new directions in theory and practice," Ronald T. Rust and Richard L. Oliver, eds., Thousand Oaks, CA: Sage Publications, pp.1-19, (1994)

[4] Oliver R. L., "Measurement and evaluation of satisfaction process in retail setting," Journal of Retailing, vol.57, pp.25-48, (1981)

[5] Engel J. F., Blackwell R. D., and Kolat D. T., "Consumer behavior (4th ed.)," NY: The Dryden Press (1982)

[6] Anderson R. E. and Weitz B., "The use of pledges to build and sustain commitment in distribution channels," Journal of Marketing Research, vol.29, pp.18-34, (1992)

[7] Xie-Yani, "The impact of Chinese visitors' satisfaction with hotel selection attributes on intention of revisit and recommendation," M.S. thesis, Dae-Gu Catholic University, pp.17-18, (2018)

[8] Yingying Fang, "The effects of Seoul tourist hotel services scape on customer satisfaction, revisit intention and recommend intention,” M.S. thesis, Gong-Ju University, pp.21, (2018) 
An Empirical Study on the Effect of Management Service Quality of High-rise Apartment on Residential Satisfaction: Focused on High-rise Apartment in China

This page is empty by intention. 